Proc $2^{\text {nd }}$ APCRS

\title{
Reproductive biology of nocturnal reef fish Pempheris sp. (Pempherididae) in Okinawa Island, Japan
}

\author{
Keita KOEDA ${ }^{1, *}$, Takanobu FUKAGAWA ${ }^{2}$, Taiki ISHIHARA ${ }^{1}$ and Katsunori TACHIHARA ${ }^{2}$ \\ ${ }^{1}$ Graduate School of Engineering and Science, University of the Ryukyus, Nishihara, Okinawa, 903-0213, Japan \\ ${ }^{2}$ Faculty of Science, University of the Ryukyus, Nishihara, Okinawa, 903-0213, Japan \\ * Corresponding author: K. Koeda \\ E-mail: hatampo@gmail.com
}

\begin{abstract}
Reproductive characteristics of Pempheris sp. were studied in 233 specimens collected from May 2006 to October 2010 on Okinawa Island, Japan. The main spawning season was estimated during April to June, but spawning occurred year round. Standard length at first maturity occurred at ca. $110 \mathrm{~mm}$ in both sexes. Batch fecundity of Pempheris sp. was ca. 2,000-19,000 per female, and was higher in the main spawning season than in other seasons. No relationship between spawning and lunar periodicity was observed. The spawning interval of Pempheris sp. was estimated to be ca. 2 days, with spawning occurring shortly after sunset.
\end{abstract}

Keywords Pempheris sp., Pempherididae, reproduction, spawning season, maturation size, spawning interval, nocturnal, coral reef, Okinawa

\section{Introduction}

Fish of the genus Pempheris are one of the most abundant species in rocky and coral areas, specifically in the Indo-Pacific Ocean and western Atlantic Ocean comprising21 recognized species (Nelson, 2006). Pempheris species school in caves or crevices during the day and swim out to open water at night to prey primarily on zooplankton (Fishelson et al., 1971; Gladfelter, 1979;
Golani and Diamant, 1991; Fishelson and Sharon, 1997; Platell and Potter, 1999; Platell and Potter, 2001; Annese and Kingsford, 2005; Sazima et al., 2005).

Golani and Diamant (1991) showed that the spawning season of $P$. vanicolensis (Cuvier, 1831) is from April to September in the Mediterranean Sea and throughout the year in the Red Sea. However, they did not conduct histological research, and little is known about the life history of Pempheris species in the Pacific Ocean.

Recently, two Japanese new recorded species, $P$. oualensis (Cuvier, 1831) "Yume-hatampo" in Japanese name and $P$. vanicolensis "Kibire-hatampo" in Japanese name, were collected (Koeda et al., 2010 a; Koeda et al., 2010 b) from Okinawa Island and Iriomote Island, respectively. Additionally, another unknown Pempheris species (Fig. 1) was recorded in Okinawan water. This species (Pempheris sp.) was clearly distinguished from other Pempherid species by its number of pored lateral-line scales (54-62), scale rows above the lateral line (4 1/2), and other taxonomic characters (Koeda et al., unpublished data). Therefore, authors will report this species as undescribed species in the near future. This species named "Ryukyu-hatampo" in Japanese name, and is abundant in the coral reef areas around Okinawa Island and makes mixed schools with P. schwenkii Bleeker, 1855. The objectives of the present study were to reveal reproductive traits such as spawning season, first maturation size, batch fecundity, and spawning interval to clarify a part of the 


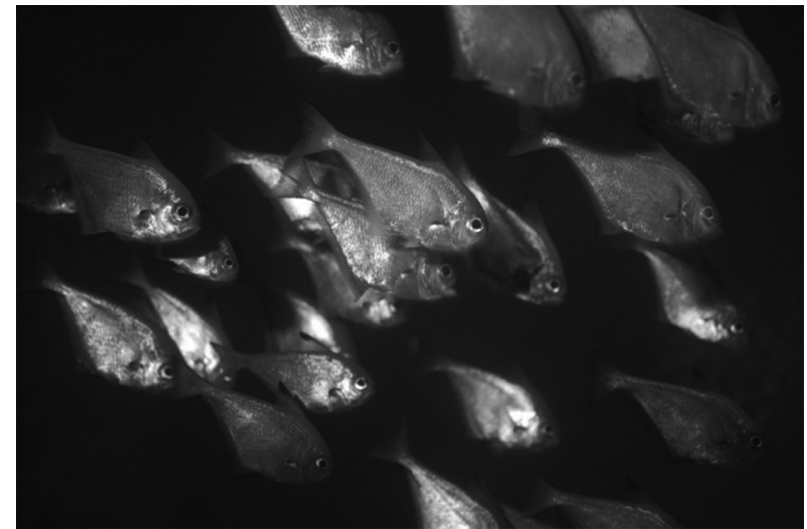

Fig. 1 A school of Pempheris sp. in cave at Maeda, Okinawa Island, Japan on 30 July 2010

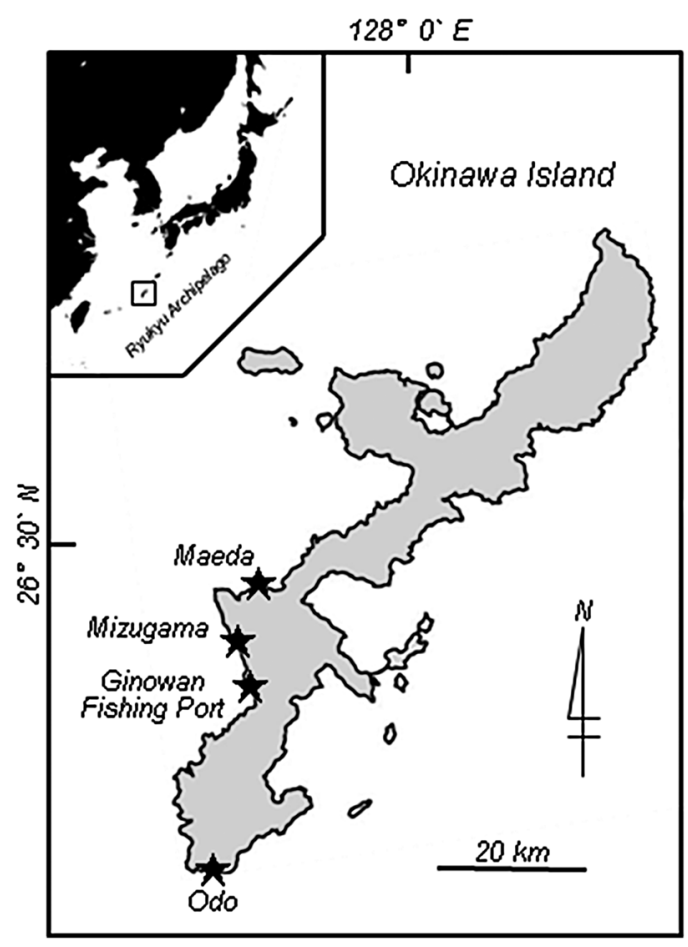

Fig. 2 Sampling sites in Okinawa Island

lifecycle of Pempheris sp. in Okinawan waters.

\section{Materials and Methods}

Specimens were caught using a trammel net (mesh size: inside $18 \mathrm{~mm}$, outside $90 \mathrm{~mm}$ ), spear gun and angling at four sites in Okinawa Island (Maeda, Mizugama, Odo, and Ginowan fishing port: $26^{\circ} 04^{\prime}-26^{\circ} 52^{\prime}, 127^{\circ} 36^{\prime}-128^{\circ}$
20': Fig. 2, Table 1) from May 2006 to October 2010 (excepting the period of May to December 2007). A total of 233 specimens (female: $\mathrm{n}=171: 65.1-156.4 \mathrm{~mm}$ in standard length: SL; male: $\mathrm{n}=62: 66.2-145.4 \mathrm{~mm} \mathrm{SL}$ ) were collected in this study. Fish were brought back to the University of the Ryukyus in a cooler filled with ice prior to measurement of SL to the nearest $0.1 \mathrm{~mm}$ and body weight (BW) to the nearest $0.1 \mathrm{mg}$. Fish larger than 50.0 $\mathrm{mm} \mathrm{SL}$ were sexed as possible from the shape of the gonads.

Water temperatures were gathered from data of the Japan Meteorological Agency (http://www.jma.go.jp/jma/ index. html) every month. Day length and lunar day were gathered from data of the National Astronomical Observatory of Japan (http://www.nao.ac.jp/).

The spawning season was estimated using 167 fish (125 females and 42 males) larger than $110.0 \mathrm{~mm} \mathrm{SL}$. Gonad weight (GW) for each fish was recorded to the nearest $0.1 \mathrm{mg}$, and the gonadosomatic index (GSI) was calculated as follows:

$$
\mathrm{GSI}=\mathrm{GW} \times 100 /(\mathrm{BW}-\mathrm{GW})
$$

For females, ovaries were fixed in Bouin's solution or $10 \%$ neutral formalin, dehydrated through an ethanol series, and embedded in paraffin. Ovaries were sectioned to a thickness of $6 \mu \mathrm{m}$ with a microtome and then stained with Mayer's hematoxylin-eosin. Then, the histologically sectioned specimens were observed under a binocular microscope. Oocytes in the ovary were classified into one of seven stages (perinucleolus, yolk vesicle, early yolk globule, late yolk globule, migratory nucleus, pre-maturation, and maturation stage) following the criteria of Yamamoto (1954) for Liopsetta obscura, Hattori et al. for Gadus macrocephalus, and Shirafuji et al. (2007) for Spratelloides gracilis. The maturity stage of each individual was determined using the most advanced oocytes in its ovary and the presence or absence of postovulatory follicles. The largest diameters of fifty oocytes in each maturational stage were measured to the nearest $0.1 \mu \mathrm{m}$ under an all purpose projector.

The spawning interval was calculated from the number of spawnable ovaries, i.e., ovaries from late yolk globule to mature stages, divided by the number of hydrated 
Table 1 Number of individuals and standard length (mean \pm SD) according to sampling site and sampling gear.

\begin{tabular}{|c|c|c|c|c|c|c|c|c|}
\hline \multirow{2}{*}{ Sampling site } & \multicolumn{4}{|l|}{ Female } & \multicolumn{4}{|l|}{ Male } \\
\hline & Trammel net & Spear gun & Angling & Total & Trammel net & Spear gun & Angling & Total \\
\hline Cape Maeda & $\begin{array}{l}3 \\
(116.4 \pm 21.3)\end{array}$ & & & $\begin{array}{l}3 \\
(116.4 \pm 21.3)\end{array}$ & $\begin{array}{l}7 \\
(105.0 \pm 16.2)\end{array}$ & & & $\begin{array}{l}7 \\
(105.0 \pm 16.2)\end{array}$ \\
\hline Mizugama & $\begin{array}{l}16 \\
(108.4 \pm 29.5)\end{array}$ & $\begin{array}{l}108 \\
(131.5 \pm 13.7)\end{array}$ & & $\begin{array}{l}124 \\
(128.5 \pm 18.3)\end{array}$ & $\begin{array}{l}13 \\
(113.3 \pm 27.9)\end{array}$ & $\begin{array}{l}29 \\
(131.6 \pm 8.8)\end{array}$ & & $\begin{array}{l}42 \\
(125.3 \pm 18.9)\end{array}$ \\
\hline Ginowan F. P. & & & $\begin{array}{l}15 \\
(115.5 \pm 11.2)\end{array}$ & $\begin{array}{l}15 \\
(115.5 \pm 11.2)\end{array}$ & & & $\begin{array}{l}6 \\
(115.0 \pm 15.2)\end{array}$ & $\begin{array}{l}6 \\
(115.0 \pm 15.2)\end{array}$ \\
\hline Odo Beach & $\begin{array}{l}21 \\
(103.6 \pm 22.7)\end{array}$ & $\begin{array}{l}8 \\
(125.9 \pm 7.9)\end{array}$ & & $\begin{array}{l}29 \\
(109.7 \pm 22.1)\end{array}$ & $\begin{array}{l}4 \\
(104.2 \pm 23.2)\end{array}$ & $\begin{array}{l}3 \\
(120.3 \pm 8.4)\end{array}$ & & $\begin{array}{l}7 \\
(111.1 \pm 20.1)\end{array}$ \\
\hline Total & $\begin{array}{l}40 \\
(106.5 \pm 25.8)\end{array}$ & $\begin{array}{l}116 \\
(131.1 \pm 13.4)\end{array}$ & $\begin{array}{l}15 \\
(115.5 \pm 11.2)\end{array}$ & $\begin{array}{l}171 \\
(123.9 \pm 20.0)\end{array}$ & $\begin{array}{l}24 \\
(109.4 \pm 24.7)\end{array}$ & $\begin{array}{l}32 \\
(129.6 \pm 9.3)\end{array}$ & $\begin{array}{l}6 \\
(115.0 \pm 15.2)\end{array}$ & $\begin{array}{l}62 \\
(123.1 \pm 19.9)\end{array}$ \\
\hline
\end{tabular}

ovaries (Demartini and Fountain, 1981). Sampling period was separated to 4 periods of time, such as morning (sunrise to $12: 00)$, afternoon (12:00 to $15: 00)$, sunset (15:00 to sunset), and night (sunset to sunrise).

Only specimens collected from sunset, which was estimated as the possible spawning time, were used for calculating the spawning interval. Only mature-stage ovaries were used for batch fecundity estimates. Ovarian walls were removed and $100.0 \mathrm{mg}$ of oocytes were weighed to the nearest $0.1 \mathrm{mg}$. Then, hydrated oocytes larger than $700 \mu \mathrm{m}$ were counted and the batch fecundity (BF) was calculated using the following formula. The samples were taken five times, the highest and lowest data were excluded, and the remaining samples were averaged.

$$
\mathrm{BF}=\mathrm{GW} / \mathrm{SW} \times \mathrm{NMO}
$$

where SW is the sample weight, and NMO is the number of oocytes larger than $700 \mu \mathrm{m}$ in the sample.

\section{Results}

\section{Oogenesis}

\section{Perinucleolus stage (Fig. 3a)}

The oocytes in this stage ranged from 16.5 to $122.8 \mu \mathrm{m}$ (mean \pm SD: $70.1 \pm 25.0 \mu \mathrm{m}$; Table 2). The cytoplasm gradually increased in volume and became deeply stained with hematoxylin early in this stage, and it was less reactive to hematoxylin later in this stage. The GSI of the females in this stage ranged from 0.01 to 1.28 (mean \pm SD: 0.45 \pm 0.30 ; Table 2).

\section{Yolk vesicle stage (Fig. 3b)}

The oocytes ranged from 158.9 to $326.5 \mu \mathrm{m}$ (222.4士 $45.2 \mu \mathrm{m}$; Table 2). Small yolk globules occurred on the periphery of the cytoplasm and increased in volume and number centripetally as the oocyte grew. The GSI of the females in this stage ranged from 0.45 to $1.45(0.90 \pm$ 0.30; Table 2).

\section{Early yolk globule stage (Fig. 3c)}

The oocytes ranged from 256.2 to $441.5 \mu \mathrm{m}$ in size (344.2 $\pm 39.8 \mu \mathrm{m}$; Table 2). Yolk globules became apparent among the yolk vesicles, forming a layer on the periphery of the cytoplasm. This stage coincided with the primary yolk globule stage in Shirafuji et al. (2007). The GSI of the females in this stage ranged from 1.10 to 1.93 (1.33 \pm 0.27 ; Table 2).

\section{Late yolk globule stage (Fig. 3d)}

The oocytes ranged from 402.6 to $656.8 \mu \mathrm{m}$ in size (518.8 $\pm 66.6 \mu \mathrm{m}$; Table 2$)$. The yolk globules rapidly increased in volume and number throughout the cytoplasm and the yolk vesicles increased against the periphery to form a layer. Ovaries with more developed late yolk globule oocytes were considered to be mature. This stage includes both secondary and tertiary yolk globule stages in Shirafuji et al. (2007). The GSI of the females in this stage ranged from 0.63 to 5.84 (2.67 \pm 1.43 ; Table 2 ).

\section{Migratory nucleus stage (Fig. 3e)}

The oocytes ranged from 419.7 to $889.7 \mu \mathrm{m}$ in size (678.5 $\pm 93.3 \mu \mathrm{m}$; Table 2). The nucleus began to move from the center to the animal pole. The yolk globules started to fuse. Oil globules appeared throughout the cyto- 

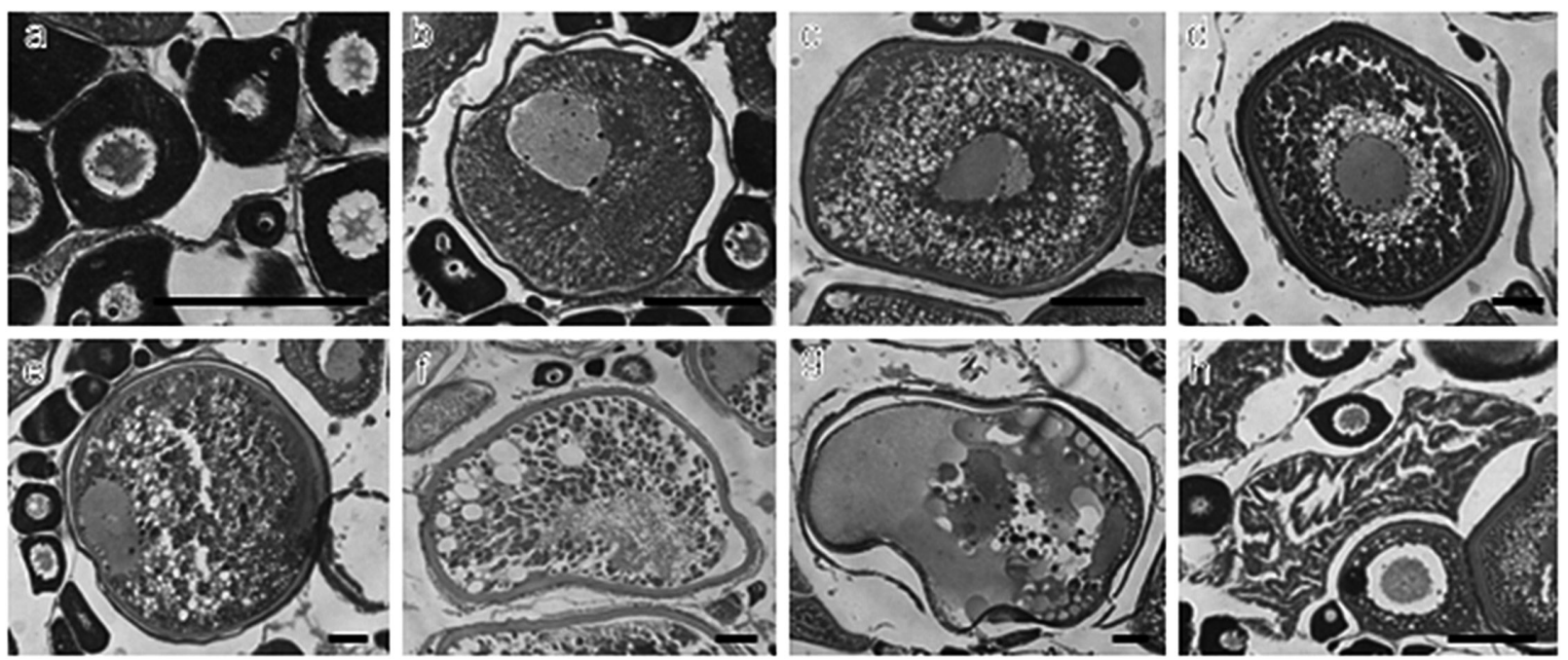

Fig. 3 Photographs of different-stage oocytes and postovulatory follicles in Pempheris sp. (a) perinucleolus stage; (b) yolk vesicle stage; (c) early yolk globule stage; (d) late yolk globule stage; (e) migratory nucleus stage; (f) pre-maturation stage; (g) maturation stage; (h) postovulatory follicles. Scale bar indicates $100 \mu \mathrm{m}$.

Table 2 Oocyte diameter and gonadosomatic index at different maturational stages. Open circle: mean; Box: standard deviation; Bars, maximum and minimum. Pn, perinucleolus stage; Yv, yolk vesicle stage; Ey, early yolk globule stage; Ly, late yolk globule stage; Mn, migratory nucleus stage; Pm, pre-maturation stage; $\mathrm{M}$, maturation stage.

\begin{tabular}{|c|c|c|c|c|c|c|}
\hline \multirow{2}{*}{$\begin{array}{l}\text { Maturation } \\
\text { stage }\end{array}$} & \multicolumn{3}{|c|}{ Oocyte diameter } & \multicolumn{3}{|c|}{ Gonadosomatic index } \\
\hline & Mean \pm SD & Max & Min & Mean \pm SD & Max. & Min \\
\hline $\mathrm{Pn}$ & $70.1 \pm 25.0$ & 122.8 & 16.5 & $0.45 \pm 0.30$ & 1.28 & 0.00 \\
\hline Yv & $222.4 \pm 45.2$ & 326.5 & 158.9 & $0.90 \pm 0.30$ & 1.45 & 0.45 \\
\hline Ey & $344.2 \pm 39.7$ & 441.5 & 256.2 & $1.33 \pm 0.28$ & 1.93 & 1.11 \\
\hline Ly & $518.8 \pm 66.6$ & 656.8 & 402.6 & $2.68 \pm 1.43$ & 5.84 & 0.63 \\
\hline $\mathrm{Mn}$ & $678.5 \pm 93.3$ & 889.7 & 419.7 & $3.36 \pm 1.20$ & 4.98 & 1.94 \\
\hline $\mathrm{Pm}$ & $707.6 \pm 117.1$ & 857.3 & 450 & $2.72 \pm 1.60$ & 4.32 & 1.11 \\
\hline M & $926.8 \pm 114.5$ & 1195.3 & 681.2 & $6.87 \pm 3.06$ & 13.24 & 2.02 \\
\hline
\end{tabular}

plasm. The GSI of the females in this stage ranged from 1.94 to 4.98 (3.36 \pm 1.20 ; Table 2$)$.

\section{Pre-maturation stage (Fig. 3f)}

The oocytes ranged from 450.0 to $827.3 \mu \mathrm{m}$ (707.6士 $117.1 \mu \mathrm{m}$; Table 2). The yolk globules coalesced further. The oil globules started to fuse and increased in volume and number. The GSI of the females in this stage ranged from 1.11 to 4.31 (2.72 \pm 1.60 ; Table 2).

\section{Maturation stage (Fig. 3g)}

The oocytes ranged from 681.2 to $1195.3 \mu \mathrm{m}$ (926.8 $\pm 114.5 \mu \mathrm{m}$; Table 2). The oocyte became translucent with the coalescence of the yolk globules and the hydration of the cytoplasm. The GSI of the females in this stage ranged from 2.02 to 13.23 (6.87 \pm 3.06 ; Table 2$)$.

\section{Seasonal changes in ovarian maturation}

Monthly changes of GSI, water temperature, and day length are shown in Fig. 4. Mature females (GSI>2.0) were observed throughout the year, except for January. The GSIs from April to June were significantly higher than other months (one-way ANOVA: $p<0.01$ ). In April, the GSI rapidly increased with increasing water temperatures and day length. However in July, the GSI rapidly decreased with the increase in water temperature to $26^{\circ} \mathrm{C}$ and the decrease in day length.

Monthly changes in the maturational stage of ovaries 

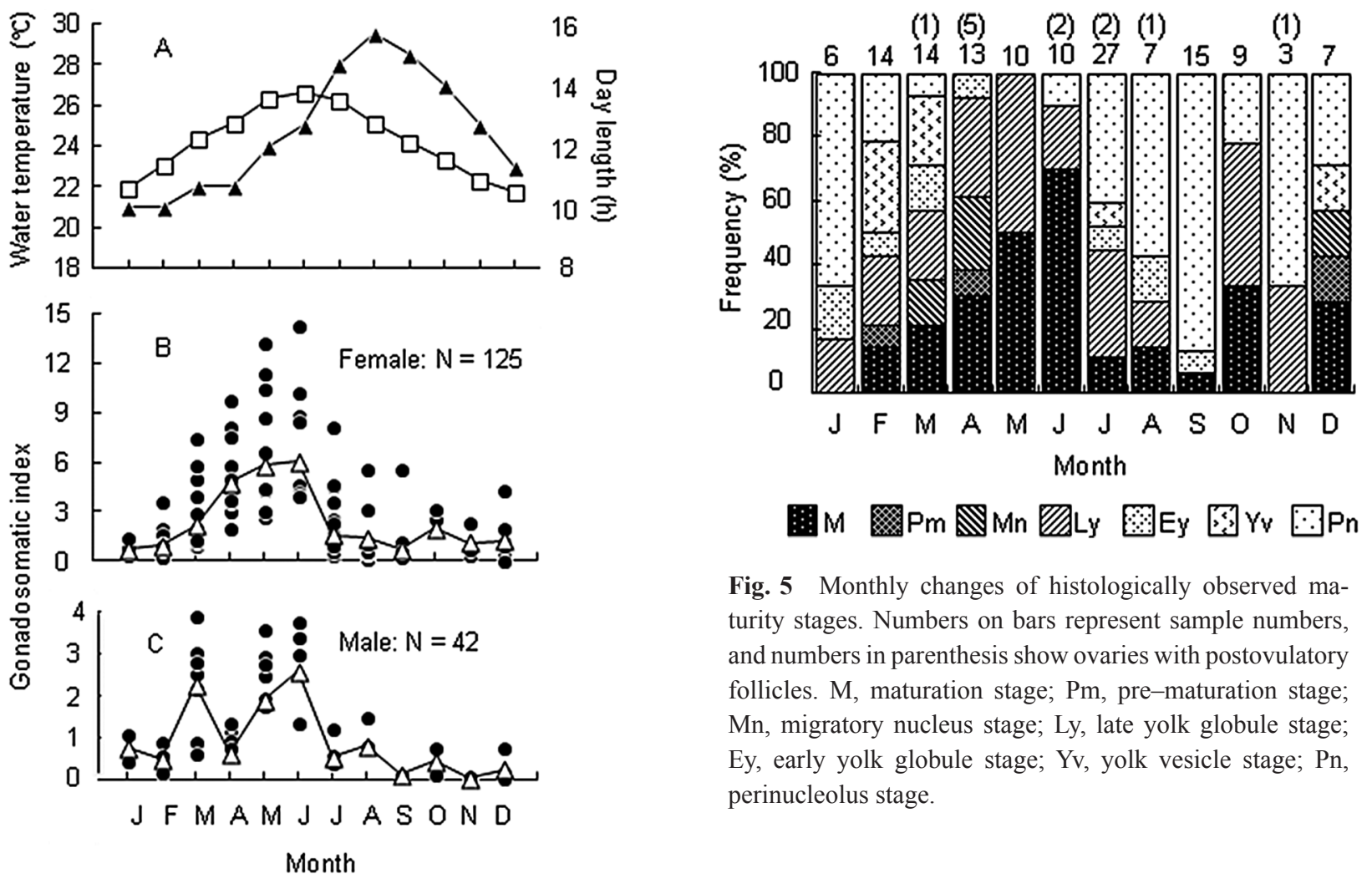

Fig. 4 A, Monthly changes in water temperature (solid triangle) and day length (open square) at Okinawa Island in 2009, from Japan Meteorological Agency and National Astronomical Observatory of Japan, respectively; B, Monthly changes in gonadosomatic index of females from Okinawa Island, Japan. C, Monthly changes in gonadosomatic index of males. Data from 2006 to 2010 are combined.

are shown in Fig. 5. Mature females appeared through the year, except for September. The frequency of mature females gradually increased from February to June. Hydrated ovaries appeared in February to August, October, and December. Postovulatory follicles were observed in March, April, June to August, and November (Fig. 3h). High GSI values, mature females, and postovulatory follicles were observed during several lunar days (Fig. 6).

\section{Maturation size, spawning time, and spawning interval}

The first appearance of mature females was at 111.1 $\mathrm{mm} \mathrm{SL}$ (GSI=2.64; Fig. 7). In males, the first appearance of high GSI fish occurred at $114.8 \mathrm{~mm} \mathrm{SL}(\mathrm{GSI}=1.74)$.

The frequency of hydrated ovaries and mature females gradually increased with the time of the day and was highest in sunset period (Fig. 8). However, the percentage

of mature females rapidly decreased, and hydrated ovaries were not observed after sunset. The spawning interval was calculated as ca. 2 days.

\section{Batch fecundity}

The months with batch fecundities with high GSI values (April to June) were calculated as 2,935-18,621 


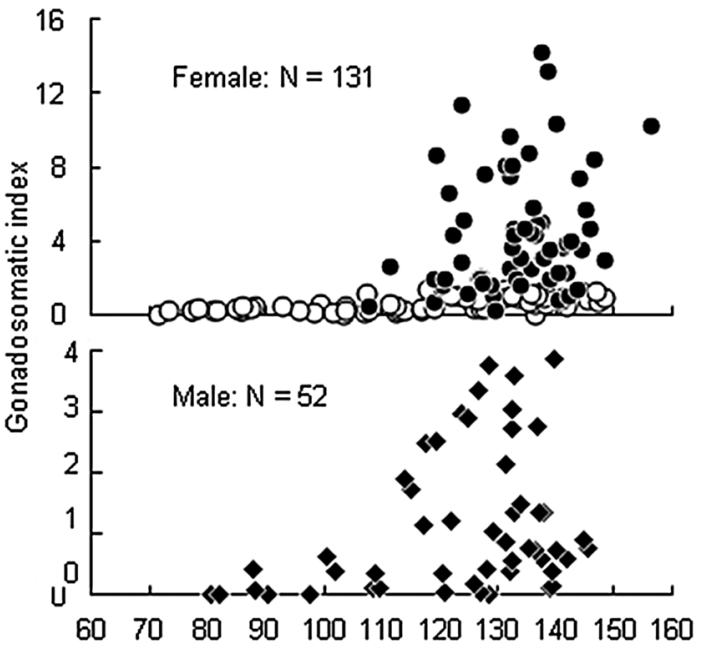

Standard length (mm)

Fig. 7 Relationship between standard length and gonadosomatic index of Pempheris sp. collected from Okinawa Island, Japan. Solid and open circles indicate mature and immature females, respectively. Data from 2006 to 2010 are combined.

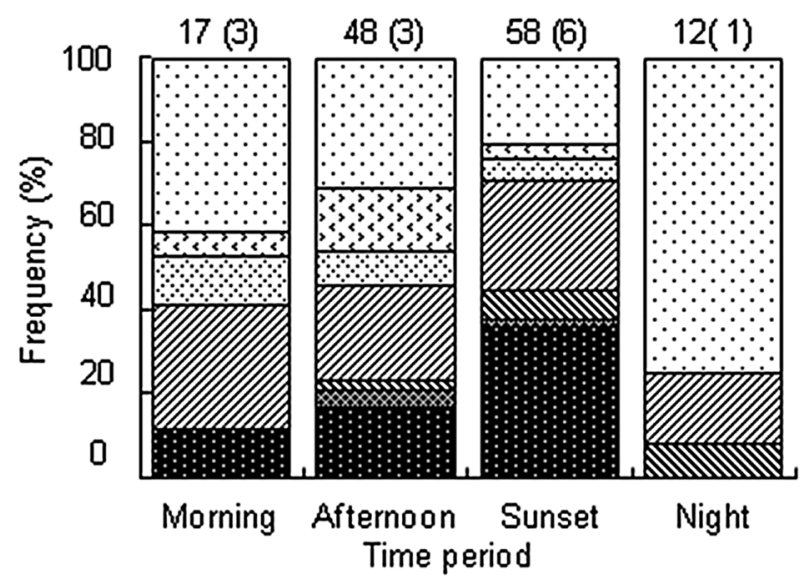

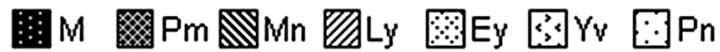

Fig. 8 Relationship between sampling period and maturity stages of ovaries. Numbers on bars represent sample numbers, and numbers in parenthesis show ovaries with postovulatory follicles. Data from all months are combined. Morning: Sunrise-12:00; Afternoon: 12:00-15:00; Sunset: 15:00-sunset; Night: sunset-sunrise. M, maturation stage; Pm, pre-maturation stage; Mn, migratory nucleus stage; Ly, late yolk globule stage; Ey, early yolk globule stage; Yv, yolk vesicle stage; Pn, perinucleolus stage.

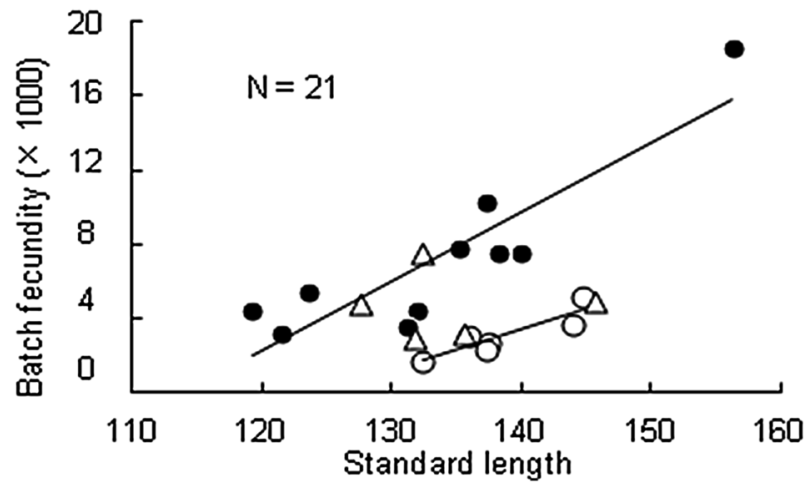

Fig. 9 Relationship between batch fecundity and standard length of Pempheris sp. collected from April to June (Solid circle), August to March (open circle), and July (open triangle) from Okinawa Island, Japan.

eggs (119.2-156.4 mm SL, $n=12$; Fig. 9). On the other hand, months with low GSI value (August to March) were calculated as 1,749-7,538 eggs (132.4-145.6 mm SL, $\mathrm{n}=6$ ). In July, just after months with peak GSI values, batch fecundity had a middle range between the high (May and June) and low (August to March) GSI monthly values. Relationships between the batch fecundities and standard length were expressed as follows.

$\mathrm{BF}($ High GSI months $)=378 \times \mathrm{SL}-43,528\left(\mathrm{r}^{2}=0.75\right)$

$\mathrm{BF}($ Low GSI months $)=225 \times \mathrm{SL}-28,126\left(\mathrm{r}^{2}=0.81\right)$

\section{Discussion}

The spawning interval of this species was about two days, and spawning was not related to the lunar cycle. Most coral reef fish spawn according to the lunar cycle (Johannes, 1978; Doherty, 1983; Takemura et al., 2004 a; Takemura et al., 2004 b; Nanami et al. 2010). The spawning pattern of this species has previously been reported in a few coral reef fish, such as butterfly fish (Ralston, 1981). A relatively high ratio of hydrated ovaries appeared in fish collected before sunset, and hydrated ovaries were not observed during the night. These facts suggest that Pempheris sp. spawn just after sunset. Several studies suggest nocturnal migration of the fish in this family; some Pempheris species emerge in open water from the diurnal shelter, and a high amount of fish gather 15 to 45 minutes after sunset (Fishelson et al., 1971; Gladfelter, 
1979; Golani and Diamant, 1991).

Therefore, nighttime observation during the main spawning season is necessary to demonstrate the exact spawning time of this species. These characteristics, such as the short spawning interval, the spawn timing apparently unaffected by the lunar day, and spawning just after sunset, may be common reproductive traits of nocturnal fish. However, it is necessary to clarify the reproductive characteristics of other nocturnal fish.

The gonadosomatic index and the presence of mature females gradually increased from April to June and were low after July. Additionally, the appearance of mature females and postovulatory follicles suggests that the main spawning season of Pempheris sp. was April to June, but it seems that spawning occurred throughout the year in Okinawan waters. However, batch fecundity was higher in the main spawning season than in other spawning seasons. In this study, the smallest sizes of mature females and males were ca. $110.0 \mathrm{~mm} \mathrm{SL}$ in both sexes, and the age of these specimens were 2 years old based on otolith observation (Koeda et al. unpublished data). These reproductive characteristics are significantly different from those of Pempheris schwenkii, which makes mixed schools with Pempheris sp. (Koeda et al., unpublished data). This fact indicates that it is necessary to clarify the reproductive traits of other Pempherid species to understand the lifecycle strategies of this genus.

\section{Acknowledgments}

We are especially grateful to Associate Professor T. Yoshino and Associate Professor H. Imai (Faculty of Science, University of the Ryukyus) for comments and advice, especially in taxonomical part. The authors thank the students of the Laboratory of Fisheries Biology \& Coral Reef Studies, Faculty of Sciences, University of the Ryukyus and the members of the University of the Ryukyus Diving Club, for their help with fish collection and for providing information. Associate Professor J. D. Reimer (Rising Star Program, University of the Ryukyus) proofread a final version of this manuscript. This study was supported in part by the Incentive Project in Scholarship and Education from the Sponsorship Group of
University of the Ryukyus.

\section{References}

Annese D, Kingsford M (2005) Distribution, movements and diet of nocturnal fishes on temperate reefs. Environ Biol Fishes 72: 161-174

Bleeker P (1855) Bijdrage tot de kennis der ichthyologische fauna van de Batoe Eilanden. Natuurkundig Tijdschrift voor Nederlandsch Indië 8: 305-328

Cuvier G (1831) Des Pemphérides. In: Cuvier G, Valen-ciennes A (eds), Historie Naturelle des Poissons. Vol. 7. F. G. Levraut, Paris, pp. 1-53, pls.170-208

Demartini EE, Fountain RK (1981) Ovarian cycling frequency and batch fecundity in the queenfish, Seriphus politus: attributes representative of serial spawning fishes. Fishery Bull 79: 547-560

Doherty PJ (1983) Diel, lunar and seasonal rhythms in the reproduction of two: tropical damselfishe: Pomacentrus flavicauda and $P$. wardi. Mar Biol 75: 215-224

Fishelson L, Popper D, Gunderman N (1971) Diurnal cyclic behavior of Pempheris oualensis Cuv. \& Val. (Pempheridae, Teleostei). J Nat Hist 5: 503-506

Fishelson L, Sharon O (1997) Spatial and foraging behavior, diet and morphogenesis of postlarvae and juveniles of Pempheris vanicolensis in the Gulf of Aqaba, Red Sea. J Fish Biol 51: $251-265$

Gladfelter WB (1979) Twilight migrations and foraging activities of the Copper Sweeper Pempheris schomburgki (Teleostei: Pempheridae). Mar Biol 50: 109-119

Golani D, Diamant A, (1991) Biology of the sweeper, Pempheris vanicolensis Cuvier \& Valencienns, a Lessepsian migrant in the eastern Mediterranean, with a comparison with the original Red Sea population. J Fish Biol 38: 819-827

Hattori T, Sakurai Y, Shimazaki K (1992) Maturation and reproductive cycle of female Pacific cod in waters adjacent to the southern coast of Hokkaido, Japan. Nippon Suisan Gakkaishi 58: 2245-2252

Johannes RE (1978) Reproductive strategies of coastal marine fishes in the tropics. Environ Biol Fishes 3: 65-84

Koeda K, Imai H, Yoshino T, Tachihara K, (2010) a. First and northern record of Pempheris oualensis (Pempheri-didae), from Ryukyu Archipelago, Japan. Biogeogr 12: 71-75

Koeda K, Yoshino T, Imai H, Tachihara K, (2010b). Description of new and northernmost record of a Pemphrididae fish, 
Pempheris vanicolensis, collected from Iriomote Island, southern Ryukyu Archipelago, Japan. Biogeogr 12: 77-82

Nanami A, Okuzawa K, Yamada H, Suzuki N, Aonuma Y (2010) Reproductive activity in the checkered snapper, Lutjanus decussates, off Ishigaki Island, Okinawa. Ichthyol Res 57: 314-318

Nelson JS (2006) Fishes of the world. Hoboken, New Jersey. John Wiley \& Sons, Inc., pp. 1-601

Platell ME, Potter IC (1999) Partitioning of habitat and prey by abundant and similar-sized species of the Triglidae and Pempherididae (Teleostei) in coastal waters. Est Coast shelf Sci 48: 235-252

Platell ME, Potter IC (2001) Partitioning of food resources amongst 18 abundant benthic carnivorous fish species in marine waters on the lower west coast of Australia. J Exp Mar Biol Ecol 261: 31-54

Ralston S (1981) Aspects of the reproductive biology and feeding ecology of Chuetodon miliaris, a Hawaiian endemic butterflyfish. Environ Biol Fishes 6 (2): 167-176

Sazima C, Krajewski JP, Bonaldo RM, Sazima I (2005) The glassy sweepers' way: seeking a versatile wrasse to be cleaned. Neotropical Ichthyol 3 (1): 119-122

Shirafuji N, Watanabe Y, Takeda Y, Kawamura T (2007) Maturation and spawning of Spratelloides gracilis Clupeidae in temperate waters off Cape Shionomisaki, central Japan. Fisheries Sci 73: 623-632

Takemura A, Rahman MS, Nakamura S, Park YJ, Takano K (2004a). Lunar cycles and reproductive activity in reef fishes with particular attention to rabbitfishes. Fish and Fisheries 5: 317-328

Takemura A, Sushilo ES, Rahman MDS, Morita M (2004b). Perception and possible utilization of moonlight intensity for reproductive activities in a lunar-synchronized spawner, the golden rabbitfish. J Exp Zool 301 (A): 844-851

Yamamoto K (1954) Studies on the maturity of marine fishes 2. Maturity of the female fish in the flounder, Liopsetta obscura. Bull Hokkaido Reg Fisheries Res Lab 11: 68-77

C Japanese Coral Reef Society 